\title{
Legal Aspects of BPJS as National Health Insurance
}

\author{
Ratna Komala Dewi ${ }^{1}$, Evita Isretno Israhadi ${ }^{2}$ \\ University of Borobudur, Jl. Pemuda, RT.1/RW.3, Rawamangun, Kec. Pulo Gadung, DKI \\ Jakarta 13220, Indonesia ${ }^{1,2}$ \\ \{ratna.komaladewi1978@gmail.com¹,evita_isretno@borobudur.ac.id²
}

\begin{abstract}
The Social Security Administering Body (BPJS) is the Indonesian government agency to handle national health insurance. Armed with the concept of cooperation, BPJS is expected to manage the participants' finances to become the national health guarantor in Indonesia. This paper uses a normative legal research approach to see the legality aspects of the BPJS in carrying out its duties as a national health guarantor. Health insurance is the state's responsibility, so the state is obliged to create a national health insurance system that is fair to all Indonesian people. All the people in this country have their rights fulfilled for good health services.
\end{abstract}

Keywords: health insurance; legality; the role of the state

\section{Introduction}

Health Insurance Regulatory Agency (BPJS) is an institution that the government gives the task to be responsible for implementing national health insurance. Must put yourself on the side as mutual insurance based on the principle of mutual assistance. Human activities are always fraught with risk, which comes from various unexpected things and may threaten human life, such as dying, suffering from a disease, accident, or property loss. This is what often triggers planning in stepping to make a plan. The risks faced can undoubtedly be managed, minimally minimized. Efforts that humans can make to overcome risks are as follows: avoiding, dissing, or avoidance is a way of dealing with risk. A person who stays away or avoids an object full of danger means he or she tries to prevent the threat itself. Second, avoiding risk may be resolved so that some harmful consequences that are not stopped can be avoided. Third, transfer (Vandawati, Sabrie, and Dian 2016).

With this model, a diverting risk means that a person who faces the risk asks another person or party to accept that risk. The transfer of risk is done with a deal and included in this case coverage (insurance). Fourth, accept (assumption or retention). Through this model means a person has prepared to accept the risks he or she is taking. That could be because the risks faced are not too great.

Efforts are taken to mitigate the risks depending on each individual's choice by paying attention to the conditions that were experienced at the time. In conducting risk management or risk management, businesses and household-scale financial planning tend to transfer risks to other parties. Insurance is an essential element in financial planning, but due to low public awareness and oblique myths circulating in the community around insurance, people are 
reluctant to buy insurance products. A lot of the question that arises in society is, how important is insurance in life? The answer is fundamental (Thabrany 2009).

Indonesians are not used to the name of insurance. Whenever an insurance agent comes close, most of us will try to stay away and reject it. Whereas when viewed with a broader perspective, insurance is a necessity. People can not be sure that this body will always be healthy and ready to perform various activities. That is what makes insurance a must to guarantee the cost of treatment when sick. Every pain, the prices that must be incurred are sometimes unpredictable.

It may not cost too much for mild diseases such as fever, headache, cough, and cold. But what if the illness that attacks us is a moderately severe disease such as dengue fever, typhus, hepatitis, and heart. Of course, the cost to be incurred is enormous. So indeed, we have to be hospitalized, and the price can penetrate tens of millions of rupiah. That's why insurance is so important to cover the cost of care when sick.

Indonesia has approximately 250 million people, but only 148 million people $(63.18 \%)$ have health insurance, which means there are still 102 million people in Indonesia who do not have health insurance (Thabrany 2009). Every country wants a good health status of the country, including Indonesia. It is time for Indonesia to guarantee the entire population of Indonesia so that every Indonesian can get health services so that it is expected to improve the national health status. The guarantee that can be applied in Indonesia is social health insurance. Many people understand that insurance is an important thing. But what is the power? The amount of premiums to be paid becomes a barrier for us to take insurance products. Instead of paying insurance premiums, the money is better used to meet more critical basic needs. The government realizes that then launched the BPJS (Social Security Administering Agency) Health program. An affordable health insurance product managed directly by the government.

Starting from January 1, 2014, the government officially implemented health programs through BPJS. The implementation of this program is under the mandate of the BPJS Health Law, namely Law 40 of 2004 on the National Social Security System (in the future referred to as the JSN Law) and Law 24 of 2011 on Social Security Organizing Bodies (starting now referred to as the BPJS Law). Until 2019 targeted, all citizens have signed up for this program. Through this program, the government wants to ensure cheap health services even for people who cannot afford free for all citizens (Christasani and Satibi 2016).

BPJS has a legal basis in the form of legislation that the House of Representatives has passed. Undeniably, BPJS is a program that uses careful planning to realize an excellent social security system (Sabrina 2015). But even though BPJS already has a legal basis that the House of Representatives has passed, BPJS must also manage funds derived from the Healthy Indonesia Card (KIS), the flagship program of President Joko Widodo during his 2-term term. How BPJS owns legal aspects in managing health insurance in Indonesia. (Yuniar and Handayani 2016)

\section{Methods}

This paper uses a normative legal research approach to see the legal aspects of BPJS in carrying out its duties as a national health guarantor. This research examines several things related to the portrait of national health insurance in Indonesia and the formal legal BPJS Health as the National Health Insurance System organizer that we will discuss in this paper. 


\section{Discussion}

\subsection{National Health Insurance}

Economic growth in Indonesia over time has a significant impact on people's lives (Dahliana 2019). It influences Indonesians' mindset and lifestyle in search of better livelihoods by finding jobs in major cities. The high level of urbanization in Indonesia causes population buildup in significant cities, congestion, air and noise pollution, garbage and waste buildup, etc. The condition also affects lifestyle changes where jobs in big cities require more Indonesians to stay in place in a work that triggers high stress, an incomparable diet and tends to choose unhealthy practical foods, and an elevated level of individualism characterized by less interaction in social relations between communities. Some of these descriptions are the root of health disorders that occur in most people in Indonesia, such as increased blood pressure, increased blood sugar, increased fat levels, and an increase in weight that is not ideal. Therefore, the Indonesian government must play an active role in health-related matters because it has a massive impact on Indonesia's survival and economic growth.

The United Nations Declaration on Human Rights in 1948, through Article 25 paragraph 1, states that everyone is entitled to an adequate life sentence for the Health and well-being of himself and his family, including the right to food, clothing, housing, and health care and social services are required and entitled to guarantees when unemployed, suffering from illness, disability, widowhood/widower, reaching old age or other circumstances that result in the lack of living, which is beyond his control (Djasri, Rahma, and Hasri 2016). The same is also recognized in our constitution, where Indonesia recognizes citizens' human rights for Health as outlined in Article $28 \mathrm{H}$ and Article 34 of the Constitution of the Republic of Indonesia of 1945 (after this referred to as the 1945 Constitution). Also, in Law No. 36 of 2009 on Health (from now on referred to as the Health Law), it is asserted that everyone has the same rights in gaining access to resources in the field of Health and obtaining safe, quality, and affordable Health, on the contrary everyone also must participate in social health insurance programs (Karim, Moenta, and Riza 2018). With this in mind, the Indonesian government needs to regulate Indonesia's national health insurance through the SJSN Law.

SJSN, as stated in Article 4 No. 40/2004, is organized based on the principles:

a. The principle of membership this principle is realized in the mechanism of mutual assistance from able participants to underprivileged participants in compulsory participation for all people, low-risk participants helping the high-risk and healthy participants assisting the sick. Through this principle of membership, social security can foster social justice for all Indonesians;

b. The nonprofit principle that the management of the trust fund is not intended to seek profit for the social security organizing body, but rather to fulfill the most significant interests of participants;

c. The principles of openness, prudence, accountability, efficiency and effectiveness, these management principles are applied and underlie all fund management activities derived from the contributions of participants and the results of their development;

d. Principles of prudence, careful, thorough, safe, and orderly management of funds;

e. Principles of accountability, implementation of programs and financial management that are accurate and accountable;

f. The portability Principle, that social security is intended to provide sustainable protection even if participants change jobs or places of residence, but still within the territory of the Unitary State of the Republic of Indonesia. The increasing economic growth of the 
smoother transportation of the archipelago and the expansion of government and private sector businesses throughout the archipelago cause the population will move more often;

g. The principle of compulsory participation is intended for all Indonesians to be participants even though their application still adjusts and considers the people and the government's economic capabilities and the feasibility of implementing the program. Participants start from workers in the formal sector and workers in the informal sector who can become participants of voluntary events;

h. The principle of the mandate fund that the funds raised from the participants' dues is a deposit to the organizing bodies to be managed as best as possible to optimize, and that is for the welfare of participants;

i. The principle of the management of the national social security fund that the proceeds in the form of dividends from shareholders are returned to benefit national security participants.

Based on the description of these principles, Law No. 40/2004 is intended to provide an appropriate basic guarantee for the entire community because it becomes the constitutional obligation of the government to its people that must be managed directly by the government to create equality and justice throughout the Unitary State of the Republic of Indonesia (Geswar and Balqis 2014).

Health insurance is one of the 5 (five) social security mandated in the SJSN Law. The health insurance is called National Health Insurance (JKN), carried out by the Social Security Organizing Agency (BPJS) health as stated in the BPJS Law. The following are related laws and regulations that can be used as a reference in the implementation of JKN (Vandawati, Sabrie, and Dian 2016), among others:

a. Law No. 40 of 2004 on The National Social Security System (SJSN);

b. Law No. 24 of 2011 concerning Social Security Administering Bodies;

c. Government Regulation Number 101 of 2012 concerning Recipients of Health Insurance Contributions;

d. Presidential Regulation No. 12 of 2013 concerning Health Insurance;

e. Presidential Regulation No. 111 of 2013 concerning Amendment to Presidential Regulation No. 12 of 2013 concerning Health Insurance;

f. Presidential Regulation No. 107 of 2013 concerning Certain Health Services Related to the Operations of the Ministry of Defense, TNI, and POLRI;

g. Regulation of the Minister of Health No. 71 of 2013 concerning National Health Insurance Health Services;

h. Regulation of the Minister of Health of the Republic of Indonesia Number 69 of 2013 concerning Standard Tariffs on Health Services in First-Level Health Facilities and Advanced Health Facilities in the Implementation of Health Insurance Programs;

i. BPJS Health Regulation No. 1 of 2013 concerning the Implementation of Health Insurance;

j. Circular Letter of the Minister of Health of the Republic of Indonesia Number HK/Menkes/31/I/2014 concerning the Implementation of Health Service Tariff Standards in First-Level Health Facilities and Advanced Health Facilities in the Implementation of Health Insurance Programs;

k. Circular Letter of the Minister of Health of the Republic of Indonesia No. HK/Menkes/32/I/2014 concerning the Implementation of Health Services in First-Level Health Facilities and Advanced Health Facilities in the Implementation of Health insurance programs. 
The definition of a national health insurance program is "a social security program that guarantees the cost of health care and the fulfillment of essential Health needs to be organized nationally in a cooperative manner mandatory by all Indonesians by paying periodic dues or dues paid by the government to the nonprofit health social security managing bodies (Sudrajat, Kunarti, and Nasihuddin 2020).

Another understanding can be found in Article 1 number 1 of Presidential Regulation No. 12 of 2013 concerning Health Insurance (from now on referred to as The Health Insurance Regulation), stipulates that what is meant by health insurance is a guarantee in the form of health protection so that participants get health care benefits and safety in meeting the basic health needs provided to everyone who has paid dues or dues paid by the government.

According to Article 19, paragraph 1 of the SJSN Law, health insurance is held nationally based on social insurance and the focus of equity. The principle of social insurance includes the gap between the rich and the poor, the healthy and the sick, the old and the young, and the high and low risk; compulsory and non-selective participation; dues based on the percentage of wages or income; nonprofit.

Implementing health insurance ensures that participants get health care benefits and protection in meeting primary health needs (Ardita 2020). The services that can be obtained from national health insurance / social health insurance include providing comprehensive benefits with affordable premiums, social health insurance applies the principle of cost control and quality, social health insurance guarantees sustainability (certainty of sustainable health care financing), and social health insurance has portability so that it can be used throughout Indonesia.

The philosophy of social security as referred to in Law No. 40/2004 is rooted in the system of capitalism because social security translates as a strategy of providing reserves to overcome systemic economic risks arising in the economic cycle of capitalism (crisis) (Yudiana, Listyaningrum, and Dwi 2020). Social security as mandated in Law No. 40/2004 is organized by four organizing bodies, namely, the Company (Persero) Social Security Workers (Social Security); Company (Persero) Savings and Insurance Fund of Public Servants (Taspen); Company (Persero) Armed Forces Insurance of the Republic of Indonesia (ASABRI); Company (Persero) Health Insurance (ASKES).

With the enactment of Law No. 24 of 2011 on Social Security Organizing Bodies (from now on referred to as Law No. 24/2011), the organizing body of social security programs, organized initially by social security managing bodies, transformed into two organizing bodies and shaped into the form of public legal entities as stated in Article 5 of Law No. 24/2011 namely BPJS Kesehatan and BPJS Ketenagakerjaan. In health insurance implementation, three essential elements are how funds are collected, how the risks are borne together, and how the funds raised are used as efficiently and effectively as possible.

Health insurance implementation consists of several interrelated aspects, namely regulatory aspects, participation aspects, benefits and dues aspects, and health aspects. All Indonesian residents must be health insurance participants managed by BPJS, including foreigners who have worked for at least six months in Indonesia and have paid dues. The group of BPJS health participants consists of two groups: the recipients of health insurance contributions and not the recipients of health insurance contributions.

The benefits obtained from BPJS participants and their families are that each participant is entitled to receive health insurance that is individual health services, including promotional, preventive, curative services, and rehabilitative, including drug services and consumable medical materials necessary medical needs. The health insurance benefits, as safely referred to, consist of medical benefits and non-medical benefits. 


\subsection{Legal Basis of BPJS}

Health is the right of all Indonesian citizens, which is included in the country's goal to promote the general welfare. It is also stipulated in the constitution (Supriyanto 2020), namely the Republic of Indonesia year 1945 (after this referred to as the 1945 NRI Constitution) as the Nation's staatsverfassung of Indonesia, as well as the laws and regulations in Indonesia. Therefore, the government as a representative and implementer of state policy must realize a healthy and prosperous society. With a healthy body, the community can be more productive and support the country to realize its ideals.

To realize this healthy society, the government has started its plan for a long time, namely in 1968. At that time, the Indonesian government issued a policy regulating health care for Civil Servants and Pension Recipients (PNS and ABRI) and their family members based on Presidential Decree No. 230 of 1968. At that time, the government also established a Health Maintenance Fund Organizing Agency (hereininal abbreviated as BPDPK), which became the national health insurance forerunner.

In 1984, the government again issued Government Regulation No. 23 of 1984, which stated that the organizing body's status was changed to Husada Bhakti Public Company. Based on Government Regulation No. 69 of 1991, 1991 the participation of health care insurance program was managed by Perum Husada Bhakti coupled with Veterans and Pioneers of Independence and their family members. Besides, with these regulations, the company can expand its membership reach to business entities and other entities as voluntary participants.

In 1992, based on Government Regulation No. 6 of 1992, Perum status was later changed to The Company (PT Persero). Considering the flexibility of financial management, contributions to the government can be negotiated for service participants and more independent direction. The government then assigned PT Askes (Persero) through the Ministry of Health of the Republic of Indonesia as the Organizer of the Poor Public Health Insurance Program (PJKMM/ASKESKIN) in 2005. On January 1, 2014, following Law No. 24 of 2011, PT Askes Indonesia (Persero) was later changed to BPJS Kesehatan.

After many years finally, on March 1, 2014, the government issued a policy related to implementing health insurance for the community whose responsibilities are given to BPJS Health. IN this BPJS program, each member must register and pay dues to get the state health facilities program.

\section{Conclussions}

BPJS is an institution mandated by the government to handle the National Health Insurance (JKN) program initiated by the government in 2014. every citizen is entitled to join BPJS Kesehatan by registering and paying his/her dues every month. BPJS Kesehatan also manages the Healthy Indonesia Card (KIS), health insurance for the poor. In this case, BPJS is covered by Law No. 24 of 2011 on National Health Insurance. Legally BPJS is strong enough to manage the national health insurance system (SJSN) because Law has covered it No. 24 of 2011. However, SJSN management needs supervision so that the government of health insurance can be adequately managed so that no budget deficit can ultimately harm BPJS health participants themselves. 


\section{References}

[1] Ardita, Mikho. 2020. "Tanggung Jawab Negara Terhadap Jaminan Kesehatan Dalam Perspektif Hak Asasi Manusia.” Jurnal HAM 11(2): 319-33.

[2] Christasani, Putu Dyana, and Satibi Satibi. 2016. "Kajian Faktor Demografi Terhadap Kepuasan Pasien Jaminan Kesehatan Nasional Pada Fasilitas Kesehatan Tingkat Pertama.” Journal of Pharmaceutical Sciences and Community 13(01): 28-34.

[3] Dahliana, Anita. 2019. "Motivasi Kepesertaan Mandiri BPJS Di Era Universal Health Coverage Jaminan Kesehatan Nasional." KELUWIH: Jurnal Kesehatan dan Kedokteran 1(1): 11-18.

[4] Djasri, Hanevi, Puti Aulia Rahma, and Eva Tirtabayu Hasri. 2016. "Korupsi Dalam Pelayanan Kesehatan Di Era Jaminan Kesehatan Nasional: Kajian Besarnya Potensi Dan Sistem Pengendalian Fraud." Integritas 2(1): 113-33. https://acch.kpk.go.id/id/component/content/article?id=672:korupsi-dalam-pelayanankesehatan-di-era-jaminan-kesehatan-nasional-kajian-besarnya-potensi-dan-sistempengendalian-fraud.

[5] Geswar, Rezky Kurnia, and Nurhayani Balqis. 2014. "Kesiapan Stakeholder Dalam Pelaksanaan Program Jaminan Kesehatan Nasional Di Kabupaten Gowa.” Jurnal AKK 3(1): 1-12.

[6] Karim, Muhammad Imanuddin Taqwa, A. Pangerang Moenta, and Marwati Riza. 2018. "Implementasi Kebijakan Pemerintah Daerah Di Bidang Kesehatan Masyarakat Melalui Jaminan Kesehatan Nasional.” Amanna gappa 26(1): 53-63.

[7] Sudrajat, Tedi, Siti Kunarti, and Abdul Aziz Nasihuddin. 2020. "Perlindungan Hukum Dan Pemenuhan Hak Pekerja Pada Program Jaminan Kesehatan Nasional.” Pandecta Research Law Journal 15(1): 83-92.

[8] Supriyanto, Eko Eddya. 2020. Eksistensi Nilai-Nilai Pancasila Dalam Kebijakan Ekonomi Indonesia. 1st ed. Malang: Literasi Nusantara.

[9] Thabrany, Hasbullah. 2009. "Badan Penyelenggara Jaminan Kesehatan Nasional: Sebuah Policy Paper Dalam Analisis Kesesuaian Tujuan Dan Struktur BPJS." Universitas Indonesia: 1-47. https://staff.ui.ac.id/system/files/users/hasbulah/material/bpjsnsionalataubpjsd.pdf\%0A Accessed: 2020-11-01.

[10] Yudiana, I Gede, Novita Listyaningrum, and Nuraini Dwi. 2020. "Perlindungan Hukum Bagi Pasien Pengguna Badan Penyelenggara Jaminan Sosial (BPJS) Di Rumah Sakit Kota Mataram.” Binawaya 14(12): 3591-3602.

[11] Yuniar, Yuyun, and Rini Sasanti Handayani. 2016. "Kepuasan Pasien Peserta Program Jaminan Kesehatan Nasional Terhadap Pelayanan Kefarmasian Di Apotek The Satisfaction of National Health Insurance P Rogram's Patients On Pharmaceutical Services in Pharmacy ( JKN ) Adalah Program Jaminan Berupa Bentuk Pel.” Jurnal Kefarmasian Indonesia 6(1): 39-48. 